\title{
The $\mathrm{CD133}^{+}$subpopulation of the SW982 human synovial sarcoma cell line exhibits cancer stem-like characteristics
}

\author{
AIGUO LIU ${ }^{1 *}$, BAOHUA FENG ${ }^{1 *}$, WENGUANG GU ${ }^{1}$, XIANGYANG CHENG ${ }^{1}$, \\ TIEJUN TONG ${ }^{1}$, HONGZHI ZHANG ${ }^{1}$ and YONGZHEN HU ${ }^{2}$ \\ Departments of ${ }^{1}$ Orthopedic Surgery and ${ }^{2}$ Neurosurgery, First Affiliated Hospital, \\ Harbin Medical University, Harbin 150001, P.R. China
}

Received November 27, 2012; Accepted January 24, 2013

DOI: $10.3892 /$ ijo.2013.1826

\begin{abstract}
Several soft tissues sarcomas have been reported to contain cancer stem-like cells (CSCs) or tumor-initiating cells, based on their ability to initiate and sustain tumor growth. However, these cells have not yet been identified in the human synovial sarcoma cell line SW982. CD133, a surface glycoprotein specific to stem and progenitor cells, has been described as a CSC marker in different tumor types. In the present study, we identified a CSC subpopulation in SW982 cells using the CD133 cell surface marker. CD133-positive $\left(\right.$ CD133 $\left.{ }^{+}\right)$cells were identified in SW982 cells (8.59\%); these cells showed an increased ability to form spherical colonies and could self-renew in serum-starved culture conditions, compared to CD133-negative (CD133') cells. Real-time PCR analysis of stemness genes revealed that the $\mathrm{CD} 133^{+}$subpopulation expresses higher levels of Bmil, c-Myc, Nanog, Oct3/4 and Sox2. CD133+ cells showed increased resistance to cisplatin (CDDP) and doxorubicin (DXR), possibly due to upregulation of the $A B C G 2$ drug transporter gene. In vivo studies revealed that the $\mathrm{CD}_{133^{+}}$subpopulation is highly tumorigenic. These findings indicate that $\mathrm{CD} 133^{+}$SW982 cells have characteristics similar to CSCs. This discovery may lead to the development of novel therapies that specifically target $\mathrm{CD}_{133^{+}}$synovial sarcoma CSCs.
\end{abstract}

\section{Introduction}

Synovial sarcoma (SS) is a high-grade malignant tumor that accounts for almost $10 \%$ of all adult soft tissue sarcomas (1). It can occur at any age and anatomical site, but is most commonly found in the para-articular regions in adolescents and young adults (2). SS is characterized by the presence of

Correspondence to: Dr Wenguang Gu, Department of Orthopedic Surgery, First Affiliated Hospital of Harbin Medical University, 23 Youzheng Street, Nan Gang District, Harbin 150001, P.R. China E-mail: guwenguang@hotmail.com

*Contributed equally

Key words: cancer stem cell, synovial sarcoma, CD133, SW982 a chromosomal translocation $\mathrm{t}(\mathrm{X} ; 18)$ (p11.2;q11.2) between chromosomes $\mathrm{X}$ and 18 that leads to the formation of a fusion protein (3).

Currently, SS is classified as a miscellaneous tumor of uncertain histological origin (4), which is thought to arise from undifferentiated mesenchymal cells. A recent report indicates that neural crest cells, which can differentiate into both ectoderm and mesoderm, are potential progenitors of SS (5). However, the cellular origin of SS has not been definitively resolved.

Clinically, SS appears as deep-seated slowly growing mass, with more than half of patients developing metastases, mainly to the lungs and sometimes to the lymph nodes and bone marrow (6). The 5- and 10-year survival rates are as low as 36 and $20 \%$, respectively (7). Thus, SS remains a cancer associated with high morbidity and therefore, improved therapies are necessary.

The cancer stem-like cell (CSC) hypothesis holds that tumor cells are hierarchically organized according to their potential to initiate and sustain tumor growth. Only a small population of tumor cells, defined as CSCs or tumor-initiating cells, can form tumors in serial xenotransplantation assays, are resistant to chemotherapy and have the ability to re-establish the hierarchical cell organization and heterogeneity of the parental tumor at each passage in vivo $(8,9)$. These cells were first described in acute myeloid leukemia (10) and subsequently in breast cancer (11), prostate cancer (12), glioblastoma (13), melanoma (14) and other types of cancer (15-18). Thus, the identification of the CSCs has significantly improved our understanding of tumor biology and may lead to more effective tumor therapies.

Recent technical advances have enabled the identification of CSCs by specific surface markers that are selectively expressed on these cells, but not on the majority of tumor cells. Of these, CD133 is a pentaspan membrane glycoprotein that was first described as a surface antigen specific to human hematopoietic stem and progenitor cells (19), but has also recently been recognized as a stem cell marker in brain (20), prostate (21), pancreatic (22), lung (23) and ovarian cancers (24). CD133 expression has also been identified in various sarcomas, including osteosarcoma (25) and Ewing's sarcoma (16). CD $133^{+}$Ewing's sarcoma cells express significantly higher levels of the stemness genes Nanog and Oct3/4 than 
their CD133- counterparts. Recently, the presence of CD133+ cell populations was reported in SS (26). However, until now it was unknown whether $\mathrm{CD} 133^{+}$cells with CSC properties could be isolated from the human SS cell line SW982.

Therefore, in the present study we used CD133 as a marker to identify CSCs within the SW982 cell population. We then examined the self-renewal, differentiation capacity and tumorigenicity of the SW982 $\mathrm{CD} 133^{+}$cell population using a spheroid formation assay and xenograft model in nude BALB/c mice. We also compared chemoresistance and examined expression of the specific drug transporter, $A B C G 2$ and stemness genes in different subpopulations of SW982 cells. Our results allowed us to define the phenotype of SW982 CSCs, which may contribute to the development of more effective therapies for SS.

\section{Materials and methods}

Cell culture. The human SS cell line SW982 was obtained from the American Type Culture Collection (USA) and maintained in Leibovitz-15 medium (Gibco BRL, Grand Island, NY, USA) supplemented with $10 \%$ fetal bovine serum (FBS, Hyclone, UT, USA) at $37^{\circ} \mathrm{C}$ in a humidified atmosphere containing $5 \% \mathrm{CO}_{2}$. The culture medium was changed every 3-4 days and cells were trypsinized and replated when $85 \%$ confluency was reached.

Magnetic- and fluorescence-activated cell sorting. CD133+ and CD133-populations were isolated from SW982 cell cultures by magnetic bead sorting using a magnetic-activated cell sorting (MACS) CD133 cell isolation kit. Briefly, SW982 cells were resuspended in MACS buffer [phosphate-buffered saline (PBS) without $\mathrm{Ca}^{2+}$ and $\mathrm{Mg}^{2+}$, supplemented with $0.5 \%$ BSA and $2 \mathrm{mM}$ EDTA] at a concentration of $3.3 \times 10^{8}$ cells $/ \mathrm{ml}$. Single-cell suspensions (300 $\mu 1$, containing $1 \times 10^{8}$ cells) were incubated with $100 \mu 1 \mathrm{FcR}$ blocking reagent and $100 \mu \mathrm{l} \mathrm{CD133}$ microbeads for $30 \mathrm{~min}$ at $4^{\circ} \mathrm{C}$. After washing, cell populations were separated by passing through LS columns, which retain $\mathrm{CD} 133^{+}$cells, according to the manufacturer's instructions. Before and after separation, cell samples were analyzed by fluorescence-activated cell sorting (FACS) using anti-CD133/2 phycoerythrin (293C3) and isotype control mouse $\mathrm{IgG} 2 \mathrm{~b}$ phycoerythrin antibodies using a FACSCalibur flow cytometer (BD Biosciences, San Jose, CA, USA). All reagents were purchased from Miltenyi Biotec.

Spheroid formation assay. Spheroid formation assays were performed as described by Fujii et al (27) and Gibbs et al (28) with some modifications, using single-cell SW982 suspensions (dissociated using $0.25 \%$ trypsin $/ 0.05 \%$ EDTA at $~ 70 \%$ confluency) and both $\mathrm{CD} 133^{+}$and $\mathrm{CD} 133^{-}$cell populations isolated by MACS. Briefly, cells were resuspended in B27-supplemented Leibovitz-15/1\% methylcellulose medium without serum and containing human recombinant epidermal growth factor (EGF; $10 \mathrm{ng} / \mathrm{ml}$ ) and basic fibroblast growth factor (bFGF; $10 \mathrm{ng} / \mathrm{ml}$; PeproTech, Rocky Hill, NY, USA) and plated at $6 \times 10^{4}$ cells/ well into ultra-low attachment 6-well plates (Corning Inc., Corning, NY, USA). B27 was purchased from Invitrogen. Fresh aliquots of EGF and bFGF were added every second day. After 10-14 days, colonies containing $>50$ cells were counted using inverted phase contrast microscopy (Olympus CKX41, Shinjuku, Tokyo, Japan). Spheroid formation was investigated through at least five cycles of dissociation and re-culturing in anchorage-independent, serum-starved condition on 96-well ultra-low attachment plates.

Chemosensitivity assays. To assess the effects of cisplatin (CDDP) and doxorubicin (DXR) (Sigma), which are frequently used for sarcoma chemotherapy, on the $\mathrm{CD}_{133^{+}}$and $\mathrm{CD} 133$ cell populations, the cells were dissociated, resuspended in Leibovitz-15/10\% FBS at a concentration of $2 \times 10^{4}$ cells/ $\mathrm{ml}$, inoculated into 96-well microtiter plates (Corning Inc.) at $100 \mu \mathrm{l} /$ well and incubated at $37^{\circ} \mathrm{C}$. After $24 \mathrm{~h}$, cells were exposed to 0-10 $\mu \mathrm{M}$ CDDP or DXR for $48 \mathrm{~h}$. The viability of treated and control cells was measured by the MTS assay using the CellTiter 96 AQueous One Solution Cell Proliferation Assay kit (Promega, Madison, WI, USA), according to the manufacturer's instructions.

For a more detailed characterization of the stemness properties of the $\mathrm{CD} 133^{+}$cell population, we compared drug resistance in $\mathrm{CD} 33^{+}$spheroids and adherent cells. CD133+ adherent cells were grown in medium containing serum, as previously described. CD133 ${ }^{+}$spheroids $\left(5 \times 10^{4}\right.$ cells $\left./ \mathrm{ml}\right)$ were resuspended in B27-supplemented Leibovitz-15/1\% methylcellulose medium, plated into 96-well ultra-low attachment microplates at $100 \mu \mathrm{l} /$ well and incubated at $37^{\circ} \mathrm{C}$ for 14 days to induce spheroid formation. $\mathrm{CD} 133^{+}$spheroids and adherent cells were then treated with $0-10 \mu \mathrm{M}$ CDDP or DXR and cell viability was measured by the MTS assay after $48 \mathrm{~h}$. Triplicate wells were used for each treatment group.

Western blotting. Western blotting was performed as described previously, with some modifications (28). Briefly, cells were washed twice with cold PBS and lysed in buffer containing $50 \mathrm{mM}$ Tris- $\mathrm{HCl}$ (pH 7.4), $150 \mathrm{mM} \mathrm{NaCl}, 1 \mathrm{mM}$ EDTA, $1 \%$ NP- $40,0.1 \%$ SDS, $1 \%$ Na deoxycholate, $1 \mathrm{mM}$ Na vanadate and protease inhibitors $(5 \mathrm{mg} / \mathrm{ml}$ pepstatin, $1 \mathrm{mM}$ PMSF, $10 \mathrm{mg} / \mathrm{ml}$ leupeptin and $1 \mathrm{mM} \mathrm{NaF}$; Sigma) for $1 \mathrm{~h}$ on ice. Lysates were clarified by centrifugation at $13,000 \mathrm{~g}$ for $10 \mathrm{~min}$ at $4^{\circ} \mathrm{C}$ and protein concentrations were measured using the BCA Protein Assay kit (Pierce, Rockford, IL, USA). Samples (30 $\mu \mathrm{g}$ total protein) were separated using $10 \%$ SDS polyacrylamide gels and transferred onto polyvinylidene difluoride membranes (Sigma). After blocking with 5\% skimmed milk for $1 \mathrm{~h}$ at room temperature, membranes were incubated overnight at $4^{\circ} \mathrm{C}$ with primary antibody diluted in Tris-buffered saline (TBS) containing 0.1\% Tween-20 (Bio-Rad Laboratories, Hercules, CA, USA) and 5\% bovine albumin (Sigma). After washing three times in TBS with $0.1 \%$ Tween-20, blots were incubated with the appropriate horseradish peroxidaseconjugated secondary antibody (Cell Signaling Technology, Beverly, MA, USA; Jackson ImmunoResearch Laboratories, West Grove, PA, USA). Immunoreactive bands were visualized using ECL Plus SuperSignal West Pico (Thermo Scientific, Rockford, IL, USA). Protein levels were normalized to GAPDH. Primary antibodies used are as follows: anti-ABCG2 (1:1000), anti-Bmi1 (1:1000), anti-c-Myc (1:1000), anti-Nanog (1:1000), anti-Oct3/4 (1:1000) and anti-Sox 2 (1:1000) were purchased from Cell Signaling Technology. GAPDH (1:5000) was purchased from Santa Cruz Biotechnology. 
A

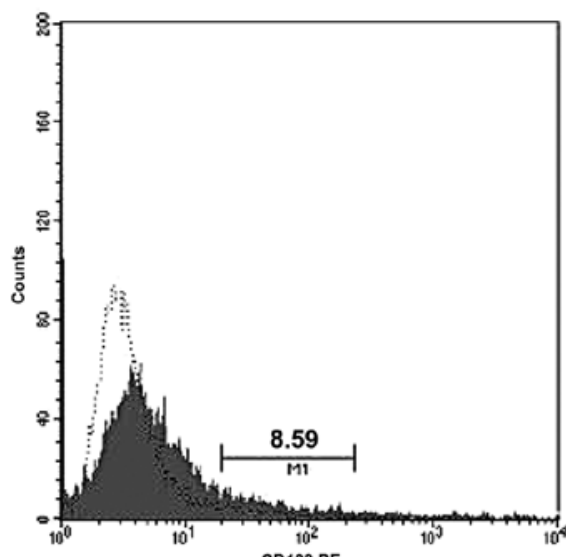

$\mathrm{B}$

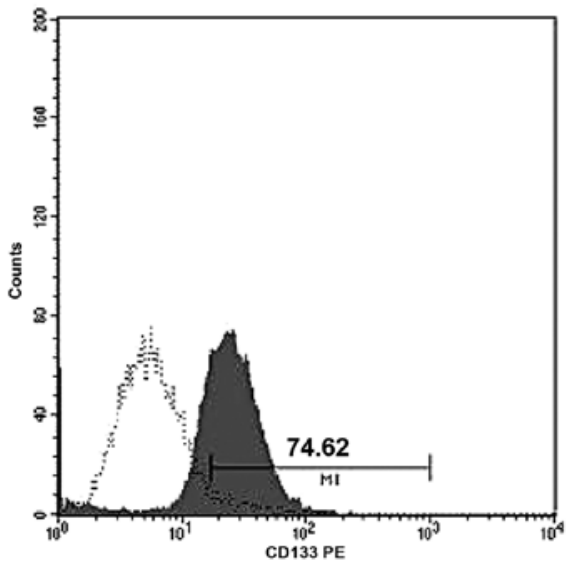

Figure 1. CD133 expression and separation in SW982 cell lines. (A) FACS analysis of CD133 expression in SW982 cell lines. (B and C) FACS analysis of $\mathrm{CD}_{133^{+}}$or $\mathrm{CD} 133^{-}$cell population after MACS sorting. Black bars and percentage indicate the ratio of $\mathrm{CD} 133^{+}$cell population. Black broken lines indicate isotype matched control. Representative data of three independent experiments are shown.

$\mathrm{C}$

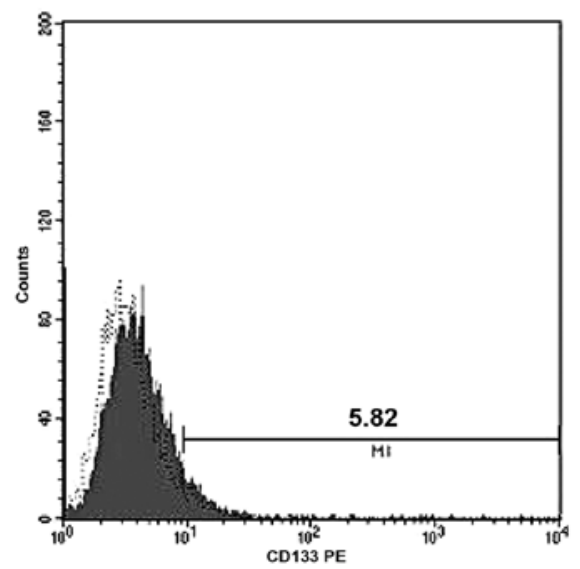

Real-time PCR. Total RNA was extracted from the CD133+ and $\mathrm{CD} 133^{-}$cell populations using TRIzol reagent (Invitrogen, Carlsbad, CA, USA) and reverse transcribed into cDNA using M-MLV reverse transcriptase (Sigma). Real-time PCR was performed according to the manufacturer's instructions using an ABI PRISM 7900HT sequence detection system (Applied Biosystems); mRNA expression was normalized to GAPDH. The primer sequences are listed in Table I.

Xenograft experiments. To evaluate the tumorigenic potential of the $\mathrm{CD}_{133^{+}}$and $\mathrm{CD} 133^{-}$cell populations, $1 \times 10^{3}-1 \times 10^{6}$ cells were subcutaneously injected into the right side of the back of 6-8-week-old female BALB/c nude mice, obtained from the Animal Research Center, Harbin Medical University, China. All surgical procedures and animal treatments were performed in accordance with institute guidelines. Mice were monitored daily for tumor growth. Twelve weeks after injection, all mice were euthanized, tumors were aseptically excised and samples were processed for histopathological and immunohistochemical analysis. In addition, tumor samples were digested using collagenase II (Sigma) and the CD133+ cells were isolated and immediately re-injected into mice to generate second-round tumors. Data were obtained from at least three independent experiments.

Histopathological and immunohistochemical analysis of xenografts. Excised xenograft tumors derived from CD133 ${ }^{+}$ and CD133 cells were fixed in $10 \%$ formalin and embedded in paraffin. Sections were cut and stained with hematoxylin and eosin (HE) using a standard protocol to assess tumor type. Immunohistochemistry was performed using an anti-CD133 antibody (Abcam, Cambridge, UK), according to standard immunohistochemical procedures. All microscopy images were captured.

Statistical analysis. Statistical software SPSS19.0 was used in data processing and analyzing. Data are expressed as mean $\pm \mathrm{SD}$, comparison between experimental groups of real-time PCR analysis were tested by one-way ANOVA. The results of the chemosensitivity assay was calculated with the survival rates and compared by using the $\chi^{2}$ test. A $p<0.05$ was regarded as statistically significant.

\section{Results}

Isolation of SW982 CD133+ and CD133- cell populations. We assessed CD133 expression in human SS SW982 cells using FACS analysis and found that $\mathrm{CD} 133^{+}$cells comprised $8.59 \%$ of the total population (Fig. 1A). We then isolated enriched $\mathrm{CD}_{133^{+}}$and $\mathrm{CD} 133^{-}$cell populations using MACS. Using this technique, the $\mathrm{CD}_{133^{+}}$cell population could be enriched by 13-fold over CD133- cells (74.62 vs. 5.82\%; Fig. 1B and C).

SW982 CD133+ cells form spheroids in suspension culture. Suspension culture in serum-free medium was initially developed as a method to select neural stem cells through neurosphere formation, but has been widely adapted as a general tumorinitiating cell selection method. Both normal cells and CSCs 
Table I. The primer sequences of the tested genes.

\begin{tabular}{lll}
\hline Gene & Forward (5'-3) & Reverse (5'-3') \\
\hline ABCG2 & GATAAAGTGGCAGACTCCAAGGT & CCAATAAGGTGAGGCTATCAAACA \\
Bmi 1 & CTCCACCTCTTCTTGTTTGC & GATGACCCATTTACTGATGATTT \\
c-Myc & GCATACATCCTGTCCGTCCA & CAAGAGTTCCGTAGCTGTTCAAG \\
Nanog & AGGCAAACAACCCACTTCT & TCACACCATTGCTATTCTTCG \\
Oct $3 / 4$ & TATTCAGCCAAACGACCATCT & TCAGCTTCCTCCACCCACTT \\
Sox2 & ATCACCCACAGCAAATGACA & CAAAGCTCCTACCGTACCACTA \\
GAPDH & GGGAAACTGTGGCGTGAT & GAGTGGGTGTCGCTGTTGA
\end{tabular}
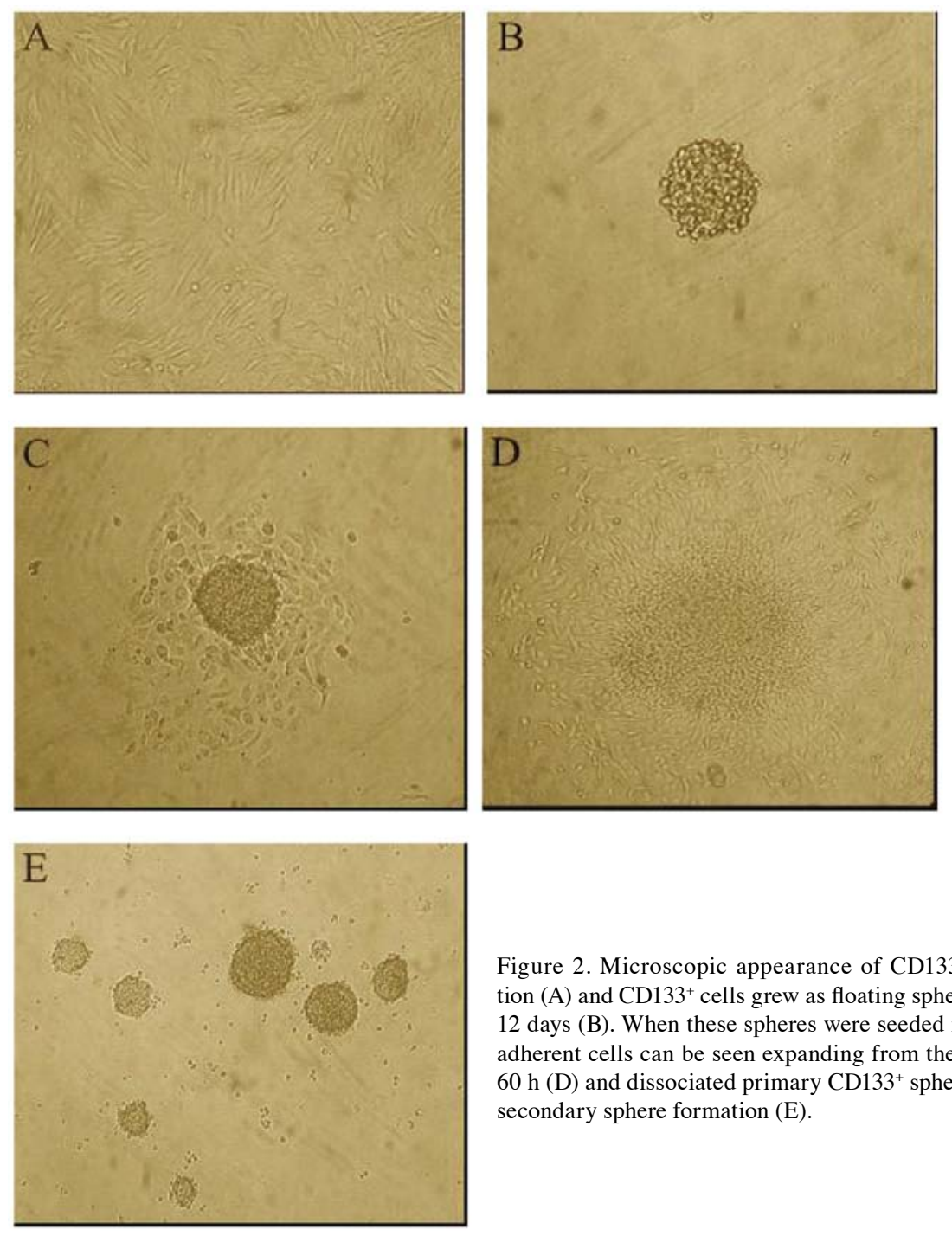

Figure 2. Microscopic appearance of $\mathrm{CD}_{133^{+}}$cells in monolayer condition (A) and $\mathrm{CD}_{133^{+}}$cells grew as floating spheres in serum-free medium for 12 days (B). When these spheres were seeded in serum containing medium, adherent cells can be seen expanding from these spheres after $20 \mathrm{~h}(\mathrm{C})$ and $60 \mathrm{~h}(\mathrm{D})$ and dissociated primary CD133+ ${ }^{+}$sphere cells showed a capacity for secondary sphere formation (E).

from epithelial organs can be grown as spherical clones in serum-free EGF/bFGF-supplemented medium that favors the proliferation of undifferentiated cells (18).

We therefore evaluated SW982 cell self-renewal and ability to generate spherical clones under serum-starved culture conditions. Our results indicated that the $\mathrm{CD} 133^{+}$subpopulation proliferated as floating spheres (Fig. 2B), while the CD133 subpopulation did not form spheres. When $\mathrm{CD} 133^{+}$spheroids were seeded into serum containing Leibovitz-15 medium, they developed the spindle-like features of the original cell culture (Fig. 2A, C and D). Primary CD133 ${ }^{+}$spheroid cells that were enzymatically disaggregated after 10-14 days of culture and replated as single-cell suspension went on to generate second passage spheres (Fig. 2E). The ability to form spheres was maintained over five serial passages using this procedure.

$\mathrm{CD} 133^{+}$SW982 subpopulations are resistant to chemotherapeutic agents. We found that CDDP and DXR inhibited the 
Table II. Cell survival rates (\%) after 48 h CDDP and DXR treatments of CD133 ${ }^{+}$and CD133 cells.

\begin{tabular}{|c|c|c|c|c|c|c|}
\hline & \multicolumn{3}{|c|}{ CDDP } & \multicolumn{3}{|c|}{ DXR } \\
\hline & $1 \mu \mathrm{M}$ & $5 \mu \mathrm{M}$ & $10 \mu \mathrm{M}$ & $1 \mu \mathrm{M}$ & $5 \mu \mathrm{M}$ & $10 \mu \mathrm{M}$ \\
\hline $\mathrm{CD}_{133}{ }^{+}$ & $93.80 \pm 1.23$ & $81.10 \pm 2.26$ & $75.54 \pm 1.83$ & $90.10 \pm 2.21$ & $76.87 \pm 1.23$ & $70.87 \pm 2.21$ \\
\hline CD133- & $76.50 \pm 1.59$ & $57.63 \pm 1.64$ & $45.63 \pm 1.30$ & $77.13 \pm 0.85$ & $48.53 \pm 2.52$ & $40.50 \pm 1.44$ \\
\hline$\chi^{2}$ & 11.84 & 12.87 & 18.71 & 6.16 & 17.11 & 18.60 \\
\hline p-value & 0.001 & 0.000 & 0.000 & 0.013 & 0.000 & 0.000 \\
\hline
\end{tabular}

Values expressed as means $\pm \mathrm{SD} \cdot \chi^{2}$ test, $\mathrm{p}<0.05$, statistical significance.

Table III. Cell survival rates (\%) after $48 \mathrm{~h}$ CDDP and DXR treatments of sphere and adherent CD133 ${ }^{+}$cells.

\begin{tabular}{|c|c|c|c|c|c|c|}
\hline & \multicolumn{3}{|c|}{ CDDP } & \multicolumn{3}{|c|}{ DXR } \\
\hline & $1 \mu \mathrm{M}$ & $5 \mu \mathrm{M}$ & $10 \mu \mathrm{M}$ & $1 \mu \mathrm{M}$ & $5 \mu \mathrm{M}$ & $10 \mu \mathrm{M}$ \\
\hline Sphere CD133+ & $96.42 \pm 2.20$ & $90.91 \pm 2.17$ & $86.30 \pm 1.20$ & $95.00 \pm 1.35$ & $89.33 \pm 1.41$ & $81.10 \pm 1.20$ \\
\hline Adherent CD133+ & $93.80 \pm 1.23$ & $81.10 \pm 2.26$ & $75.54 \pm 1.83$ & $90.10 \pm 2.21$ & $76.87 \pm 1.23$ & $70.87 \pm 2.21$ \\
\hline$\chi^{2}$ & 0.73 & 4.06 & 3.774 & 1.74 & 5.55 & 2.84 \\
\hline p-value & 0.394 & 0.044 & 0.049 & 0.187 & 0.018 & 0.092 \\
\hline
\end{tabular}

Values expressed as means \pm SD. $\chi^{2}$ test, $\mathrm{p}<0.05$, statistical significance.

$\mathbf{A}$

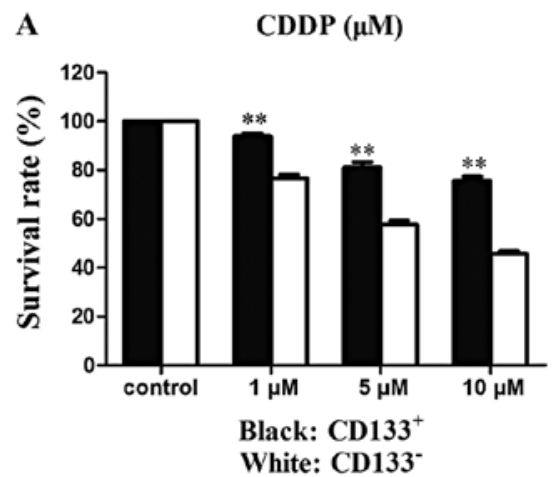

C

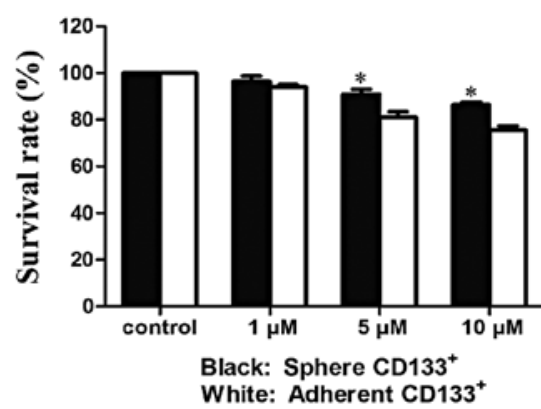

B

DXR $(\mu \mathrm{M})$

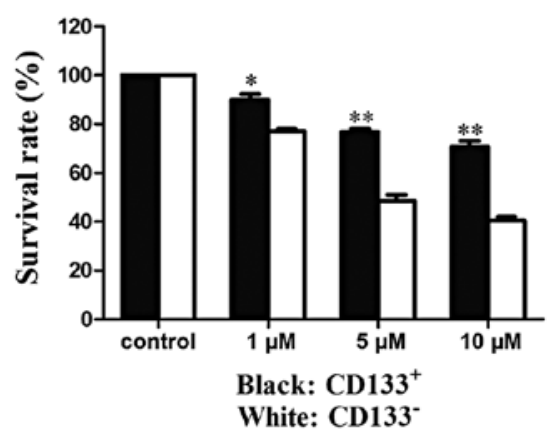

DXR $(\mu \mathrm{M})$

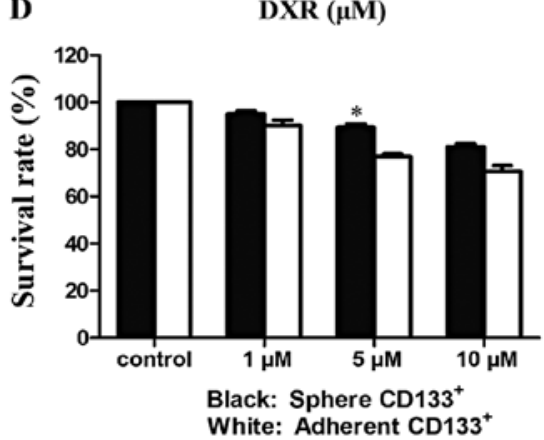

Figure 3. Drug resistance of $\mathrm{CD} 133^{+}$and CD133- cells. The $\mathrm{CD} 133^{+}$cells were highly resistant to CDDP (A) and DXR (B) in comparison with the CD133- cells The spheroids were significantly resistant to CDDP (C) and DXR (D) in comparison with the adherent $\mathrm{CD} 133^{+}$cells $\left( \pm \mathrm{SD} ;{ }^{*} \mathrm{p}<0.05 ;^{* *} \mathrm{p}<0.01\right)$.

proliferation of both $\mathrm{CD} 133^{+}$and $\mathrm{CD} 133^{-}$SW982 cell populations in a dose-dependent manner. The survival rates of $\mathrm{CD} 133^{+}$ and CD133- cells after 48-h drug treatment were measured
(Tables II and III; Fig. 3) and CD133+ cells were found to be significantly more resistant to both CDDP and DXR than CD133- cells (Fig. 3A and B): $10 \mu \mathrm{M}$ CDDP inhibited CD133- 
A Stemness and drug transporter gene

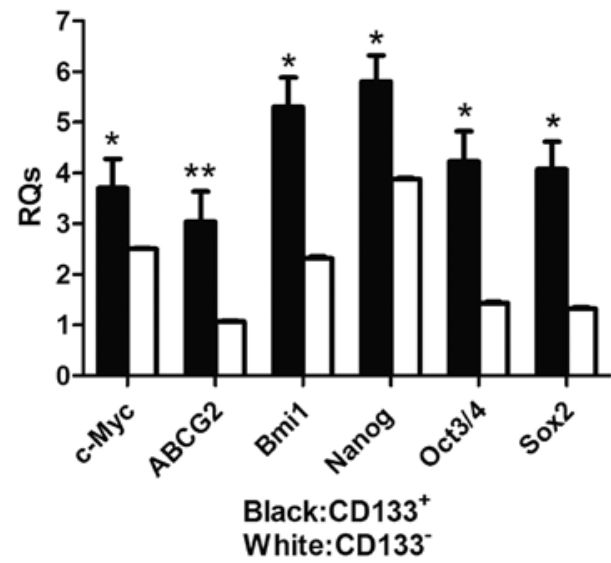

B

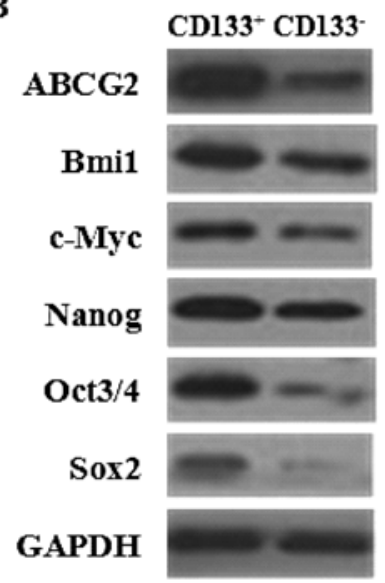

Figure 4. The gene expression profile of $\mathrm{CD}_{133^{+}}$and $\mathrm{CD} 133^{-}$subpopulations. (A) The real-time PCR analysis of stemness and drug transporter gene expression in the $\mathrm{CD}_{133^{+}}$and CD133- subpopulations $\left( \pm \mathrm{SD} ;{ }^{*} \mathrm{p}<0.05\right.$; ${ }^{* *} \mathrm{p}<0.01 ; \mathrm{RQ}$, relative quantity). (B) Western blot analysis of the stemness and drug transporter gene, GAPDH was used as a loading control.

and $\mathrm{CD}_{133}{ }^{+}$proliferation by $\leq 54.4$ and $24.5 \%$, respectively; $10 \mu \mathrm{M}$ DXR inhibited CD133- and ${ }^{-}$D133 ${ }^{+}$proliferation by $\leq 59.5$ and $30.2 \%$, respectively. These results indicate that $\mathrm{CD}_{133}{ }^{+}$cells are resistant to both CDDP and DXR, the chemotherapeutic drugs most commonly used for sarcomas. We also compared the drug response in $\mathrm{CD} 133^{+}$spheroids and adherent cells. Maximal growth inhibition of CD133+ ${ }^{+}$spheroids was $13.7 \%$ for CDDP and 19\% for DXR (Fig. 3C and D), demonstrating spheroid cells were more resistant than adherent cells to both drugs.

Increased expression of stemness and drug transporter genes in SW982 CD133+ subpopulations. Expression levels of stemness and drug transporter genes were examined in both the $\mathrm{CD}_{133^{+}}$and $\mathrm{CD} 133^{-}$subpopulations by real-time PCR and western blotting. We observed that the expression of genes that play a prominent role in stem cell maintenance and nuclear reprogramming, including Bmil, $c-M y c$, Nanog, Oct3/4 and Sox2 (29-31) were consistently higher in the $\mathrm{CD}_{133}{ }^{+}$subpopulation compared with their CD133- counterparts (Fig. 4A). However, $c-M y c$ and Bmil protein expression was not significantly increased in $\mathrm{CD}_{133^{+}}$cells in comparison
Table IV. Tumor initiating capacity of CD133+ and CD133 subpopulations.

\begin{tabular}{lccccc}
\hline & \multicolumn{5}{c}{ Cell number for injection } \\
\cline { 2 - 6 } & $1 \times 10^{3}$ & $5 \times 10^{3}$ & $1 \times 10^{4}$ & $1 \times 10^{5}$ & $1 \times 10^{6}$ \\
\hline CD133 $^{+}$ & $0 / 5$ & $2 / 5$ & $4 / 5$ & $5 / 5$ & \\
CD133 $^{-}$ & & $0 / 5$ & $0 / 5$ & $1 / 5$ & $5 / 5$ \\
\hline
\end{tabular}

with CD133- cells (Fig. 4B). In addition, both gene and protein expression of the $A B C G 2$ drug transporter was significantly increased in $\mathrm{CD}_{133^{+}}$cells compared with CD133- cells.

Increased cancer initiation by $\mathrm{CD}_{133^{+}}$cells in vivo. To investigate the tumorigenic potential of $\mathrm{CD}_{133^{+}}$and $\mathrm{CD}^{-3} 3^{-}$cells, both subpopulations of SW982 cells were injected into BALB/c nude mice to generate xenografts. A difference in tumorigenicity was observed between the $\mathrm{CD} 133^{+}$and $\mathrm{CD} 133^{-}$cell populations (Table IV). Tumor formation was observed after the injection of as few as $5 \times 10^{3} \mathrm{CD}_{133^{+}}$cells (Fig. 5A and B). In contrast, only one out of five mice injected with $1 \times 10^{5}$ CD133 cells and none of the mice injected with $\leq 1 \times 10^{4}$ CD133- cells developed tumors. CD133- cells $\left(\geq 1 \times 10^{5}\right)$ were required to initiate a tumor, suggesting that the in vivo tumorigenicity of $\mathrm{CD} 33^{-}$cells is lower than that of $\mathrm{CD}^{-3} 3^{+}$cells. In addition, $\mathrm{CD}_{133^{+}}$cells initiated both secondary and tertiary tumors, whereas CD133- cells did not.

We performed HE staining and immunohistochemistry to demonstrate that the xenografts were derived from the injected $\mathrm{CD} 33^{+}$and $\mathrm{CD} 133^{-}$cells. However, both $\mathrm{CD}^{-} 33^{+}$and CD133 tumors had similar histological characteristics and levels of CD133 expression (Fig. 5C and D).

\section{Discussion}

CSCs are present in numerous types of cancer (15) and are capable of self-renewal and differentiation and spheroid formation and have a high tumorigenicity and resistance to current treatments. In many cases, cancer therapy failure may be caused by a lack of effect of current therapies upon CSCs, which are able to survive such treatments and regenerate the tumor. It is therefore necessary to be able to detect and characterize CSCs, in order to develop new CSC-targeted therapeutic strategies. The major problems involved in isolating CSCs are their rarity and the absence of specific markers to enable their purification.

In early investigations, the side population (SP), defined by Hoechst dye exclusion, was identified as a distinct subset of cells; these cells were subsequently isolated and designated CSCs, possess stemness characteristics and are responsible for tumorigenesis in several cancer types (32-35). Some SS have been shown to contain SP with enhanced tumorigenic potential (36). We originally tried to identify SP cells in the human SS cell line SW982, but failed, possibly because of inappropriate culture conditions or lack of a stem cell population in this cell line. Aldehyde dehydrogenase (ALDH) functions as a detoxifying enzyme, has been proposed as a marker of both normal and cancer stem cells (37) and has been successfully employed 

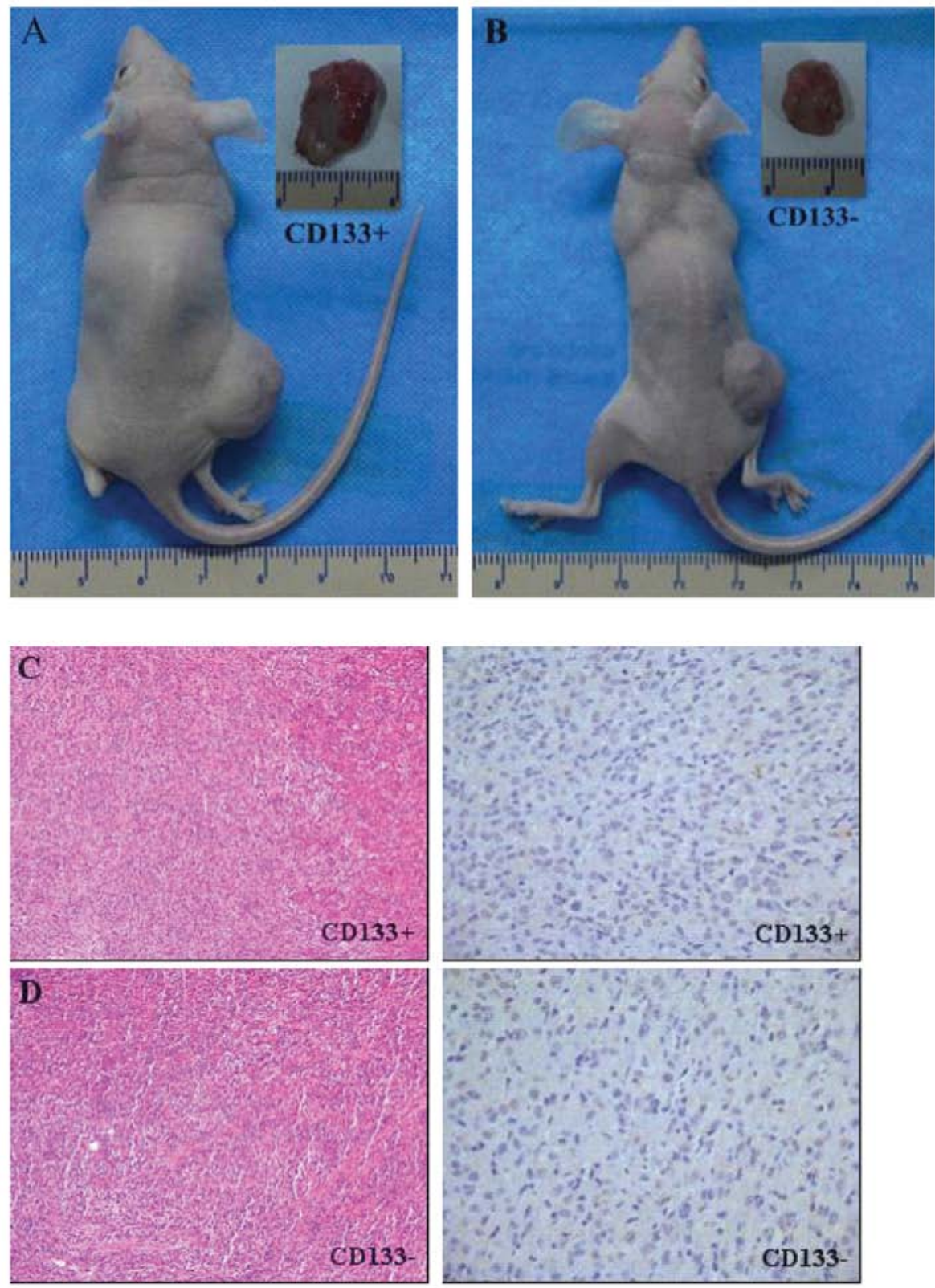

Figure 5. Analysis of tumors grown from $\mathrm{CD}_{133^{+}}$and CD133- subpopulations. (A and B) $\mathrm{CD} 133^{+}$and $\mathrm{CD} 133^{-}$cells (1x105) were subcutaneously injected into $\mathrm{BALB} / \mathrm{c}$ nude mice and gross appearance of resected tumors. (C and D) $\mathrm{CD} 133^{+}$tumor revealed histologic characteristics similar to $\mathrm{CD} 133^{-}$tumor. Left, $\mathrm{H} \& \mathrm{E}$ staining; right, expression of CD133.

A

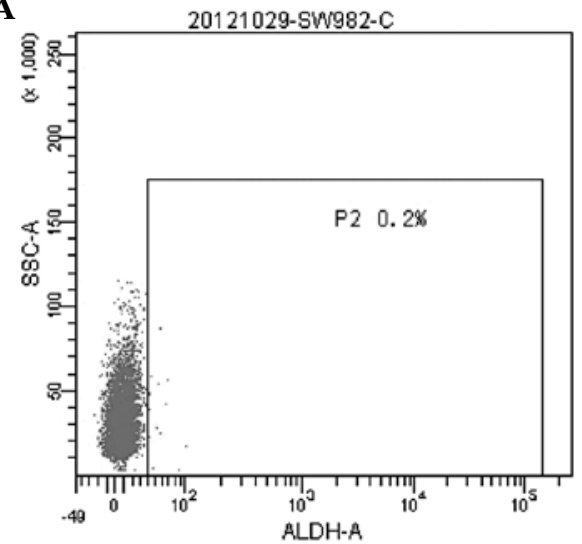

B

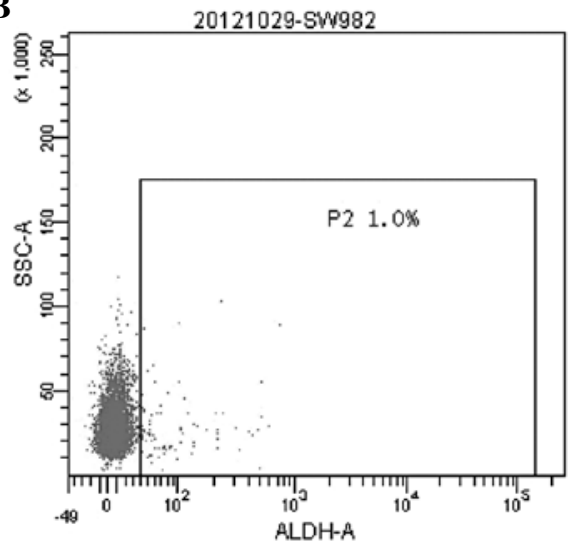

Figure 6. ALDH expression in SW982 cell lines. (A) FACS analysis of SW982 with ALDH inhibitor DEAB as a control. (B) Aldefluor assay showing 1.0\% of the cell population in SW982 express high ALDH1 activity. 
as a stem cell marker in breast (38), prostate (39), colon (40) and lung cancer (41). We demonstrated that SW982 cells contain a subpopulation with high ALDH activity, comprising $\sim 0.8 \%$ of the total cell population (Fig. 6). We also found that the $\mathrm{CD} 133^{+}$subpopulation comprises $8.59 \%$ of SW982 cells (Fig. 1A). Therefore, the CD133 antigen is potential CSC marker in SW982 cells; using this marker, we were able to isolate a population containing a high proportion of $\mathrm{CD} 133^{+}$ cells. To our knowledge, this is the first report of the analysis of CD133 expression in SW982 cells.

Two SS cell lines have been reported to exhibit sarcospheres (42). In the present study, we identified many differences between the $\mathrm{CD}_{133^{+}}$and $\mathrm{CD} 133^{-}$subpopulations; for example, $\mathrm{CD}_{133^{+}}$cells were better at forming spherical colonies and self-renewal in anchorage-independent, serum-starved culture conditions. Moreover, the $\mathrm{CD} 133^{+}$subpopulation expressed high levels of stemness genes. We compared the expression of genes that play a prominent role in stem cell maintenance, self-renewal and nuclear reprogramming, including Bmil, $c-M y c$, Nanog, Oct3/4 and Sox2, in the CD133+ and CD133 subpopulations. The $O c t 3 / 4$ transcription factor is critically involved in self-renewal and the maintenance of pluripotency in undifferentiated embryonic stem (ES) cells (43). The Sox family of transcription factors plays an essential role in cell differentiation and development. Sox 2 was originally thought to be the only Sox protein expressed in ES cells (44) and associating with $O c t 3 / 4$ to maintain ES cell self-renewal. $C$ - $M y c$ is a dominant-acting oncogene that encodes a transcription factor thought to regulate the G0-G1 cell cycle transition. Bmil is a member of the mammalian polycomb group (Pc-G) gene family (45), which contributes to the proliferative capacity and self-renewal of both normal and malignant stem cells (46). Bmil recently emerged as a Myc-cooperating oncogene (47). As both genes play an important role in stem cell maintenance, Bmil and $c-M y c$ expression may correlate with self-renewal and anti-apoptotic mechanisms in CSCs. Another highly expressed gene in $\mathrm{CD}_{133}{ }^{+}$cells is Nanog, which encodes a recently identified divergent homeoprotein that maintains ES cell self-renewal (48). All five stemness genes were consistently and significantly overexpressed in the $\mathrm{CD}_{133}{ }^{+}$subpopulation by real-time PCR. Although we did not demonstrate a relationship between expression of the encoded proteins and the genesis of SS, these data provide compelling evidence that a CD133+ subpopulation with stem-like properties exists in SW982 cells.

$\mathrm{CD}_{133}{ }^{+}$subpopulations were more resistant to the cytotoxic effects of both CDDP and DXR, showing improved survival compared to $\mathrm{CD} 133^{-}$subpopulations. In addition, $\mathrm{CD} 133^{+}$ subpopulation-derived spheroids were more drug-resistant than adherent cells. Increased expression of ABC transporter proteins, in particular $\mathrm{ABCG} 2$, is reported to significantly contribute to the CSC phenotype, strongly correlates with drug-resistance and is associated with a poor clinical outcome $(49,50)$. In our study, we revealed that $A B C G 2$ mRNA and protein expression was elevated in $\mathrm{CD} 133^{+}$subpopulations; this may be responsible for high levels of CSC multi-drug resistance and therefore constitutes a good target for clinical cancer therapy.

In addition, using a BALB/c xenograft model we observed that the $\mathrm{CD} 133^{+}$subpopulation had a higher tumorigenic potential in vivo than the $\mathrm{CD}^{2} 3^{-}$subpopulation. Furthermore, slower tumor formation was observed by the CD133- subpopulation, despite injection of more cells. This observation suggests the existence of other cell populations with tumorinitiating potential, although we cannot exclude the possibility of $\mathrm{CD}_{133^{+}}$cell contamination in the CD133- subpopulation during cell sorting procedures.

In conclusion, this study is the first to successfully isolate the $\mathrm{CD}_{133^{+}}$subpopulation from the human SS cell line SW982 and reveals that this $\mathrm{CD}_{133^{+}}$subpopulation exhibits several characteristic CSC properties, including high clonogenicity and self-renewal, increased chemotherapeutic drug resistance, elevated expression of stemness and drug transporter genes and high tumorigenic potential. Therefore, CD133 may represent a new stem cell marker for SS and may lead to novel approaches to develop therapies that selectively attack CSCs without affecting normal tissue stem cells and thus improve the prognosis for patients with SS.

\section{Acknowledgements}

This study was supported by a grant from the National Natural Science Foundation of China (no. 81072192).

\section{References}

1. Eilber FC, Rosen G, Nelson S, Selch M, Dorey F, Eckardt J and Eilber FR: High-grade extremity soft tissue sarcomas: factors predictive of local recurrence and its effect on morbidity and mortality. Ann Surg 237: 218-226, 2003.

2. Fisher C: Synovial sarcoma. Ann Diagn Pathol 2: 401-421, 1998.

3. Amary MF, Berisha F, Bernardi Fdel C, Herbert A, James M, Reis-Filho JS, Fisher C, Nicholson AG, Tirabosco R, Diss TC and Flanagan AM: Detection of SS18-SSX fusion transcripts in formalin-fixed paraffin-embedded neoplasms: analysis of conventional RT-PCR, qRT-PCR and dual color FISH as diagnostic tools for synovial sarcoma. Mod Pathol 20: 482-496, 2007.

4. Fletcher CDM, Unni KK and Mertens F (eds): Tumours of Soft Tissue and Bone. IARC Press, Lyon, pp200-204, 2002.

5. Nagayama S, Katagiri T, Tsunoda T, Hosaka T, Nakashima Y, Araki N, Kusuzaki K, Nakayama T, Tsuboyama T, Nakamura T, Imamura M, Nakamura Y and Toguchida J: Genome-wide analysis of gene expression in synovial sarcomas using a cDNA microarray. Cancer Res 62: 5859-5866, 2002.

6. Weiss SW and Goldblum JR: Enzinger and Weiss's Soft Tissue Tumors. 5th edition. Mosby Inc., St. Louis, MO, pp1161-1182, 2008.

7. Haldar M, Randall RL and Capecchi MR: Synovial sarcoma: from genetics to genetic-based animal modeling. Clin Orthop Relat Res 466: 2156-2167, 2008.

8. Reya, T, Morrison, SJ, Clarcke, MF and Weissman, IL: Stem cells, cancer and cancer stem cells. Nature 414: 105-111, 2001.

9. Milas L and Hittelman WN: Cancer stem cells and tumor response to therapy: current problems and future prospects. Semin Radiat Oncol 19: 96-105, 2009.

10. Bonnet D and Dick JE: Human acute myeloid leukemia is organized as a hierarchy that originates from a primitive hematopoietic cell. Nat Med 3: 730-737, 1997.

11. Ponti D, Costa A, Zaffaroni N, Pratesi G, Petrangolini G, Coradini D, Pilotti S, Pierotti MA and Daidone MG: Isolation and in vitro propagation of tumorigenic breast cancer cells with stem/progenitor cell properties. Cancer Res 65: 5506-5511, 2005.

12. Miki J, Furusato B, Li H, Gu Y, Takahashi H, Egawa S, Sesterhenn IA, McLeod DG, Srivastava S and Rhim JS: Identification of putative stem cell markers, CD133 and CXCR4, in hTERT-immortalized primary nonmalignant and malignant tumor-derived human prostate epithelial cell lines and in prostate cancer specimens. Cancer Res 67: 3153-3161, 2007.

13. Singh SK, Hawkins C, Clarke ID, Squire JA, Bayani J, Hide T, Henkelman RM, Cusimano MD and Dirks PB: Identification of human brain tumour initiating cells. Nature 432: 396-401, 2004. 
14. Schatton T, Murphy GF, Frank NY, Yamaura K, Waaga-Gasser AM, Gasser M, Zhan Q, Jordan S, Duncan LM, Weishaupt C, Fuhlbrigge RC, Kupper TS, Sayegh MH and Frank MH: Identification of cells initiating human melanomas. Nature 451: $345-349,2008$

15. Li C, Lee CJ and Simeone DM: Identification of human pancreatic cancer stem cells. Methods Mol Biol 568: 161-173, 2009.

16. Suvà ML, Riggi N, Stehle JC, Baumer K, Tercier S, Joseph JM, Suvà $\mathrm{D}$, Clément $\mathrm{V}$, Provero $\mathrm{P}$, Cironi L, Osterheld MC, Guillou L and Stamenkovic I: Identification of cancer stem cells in Ewing's sarcoma. Cancer Res 69: 1776-1781, 2009.

17. O'Brien CA, Pollett A, Gallinger S and Dick JE: A human colon cancer cell capable of initiating tumour growth in immunodeficient mice. Nature 445: 106-110, 2007.

18. Ricci-Vitiani L, Lombardi DG, Pilozzi E, Biffoni M, Todaro M, Peschle $\mathrm{C}$ and De Maria R: Identification and expansion of human colon-cancer-initiating cells. Nature 445: 111-115, 2007.

19. Mizrak D, Brittan M and Alison MR: CD133: molecule of the moment. J Pathol 214: 3-9, 2008.

20. Singh SK, Clarke ID, Terasaki M, Bonn VE, Hawkins C, Squire J and Dirks PB: Identification of a cancer stem cell in human brain tumors. Cancer Res 63: 5821-5828, 2003.

21. Vander Griend DJ, Karthaus WL, Dalrymple S, Meeker A, DeMarzo AM and Isaacs JT: The role of CD133 in normal human prostate stem cells and malignant cancer-initiating cells. Cancer Res 68: 9703-9711, 2008

22. Hermann PC, Huber SL, Herrler T, Aicher A, Ellwart JW Guba M, Bruns CJ and Heeschen C: Distinct populations of cancer stem cells determine tumor growth and metastatic activity in human pancreatic cancer. Cell Stem Cell 1: 313-323, 2007.

23. Eramo A, Lotti F, Sette G, Pilozzi E, Biffoni M, Di Virgilio A, Conticello C, Ruco L, Peschle C and De Maria R: Identification and expansion of the tumorigenic lung cancer stem cell population. Cell Death Differ 15: 504-514, 2008.

24. Curley MD, Therrien VA, Cummings CL, Sergent PA, Koulouris CR, Friel AM, Roberts DJ, Seiden MV, Scadden DT, Rueda BR and Foster R: CD133 expression define s a tumor initiating cell population in primary human ovarian cancer. Stem Cells 27: 2875-2883, 2009.

25. Tirino V, Desiderio V, d'Áquino R, De Francesco F, Pirozzi G, Graziano A, Galderisi U, Cavaliere C, De Rosa A, Papaccio G and Giordano A: Detection and characterization of CD133+ cancer stem cells in human solid tumors. PLoS One 3: e3769, 2008.

26. Terry $\mathrm{J}$ and Nielsen T: Expression of CD133 in synovial sarcoma. Appl Immunohistochem Mol Morphol 18: 159-165, 2010.

27. Fujii H, Honoki K, Tsujiuchi T, Kido A, Yoshitani K and Takakura Y: Sphere-forming stem-like cell populations with drug resistance in human sarcoma cell lines. Int $\mathbf{J}$ Oncol 34: 1381-1386, 2009.

28. Gibbs CP, Kukekov VG, Reith JD, Tchigrinova O, Suslov ON, Scott EW, Ghivizzani SC, Ignatova TN and Steindler DA Stem-like cells in bone sarcomas: implications for tumorigenesis. Neoplasia 7: 967-976, 2005.

29. Okita K, Ichisaka T and Yamanaka S: Generation of germlinecompetent induced pluripotent stem cells. Nature 448: 313-317, 2007.

30. Takahashi $\mathrm{K}$ and Yamanaka S: Induction of pluripotent stem cells from mouse embryonic and adult fibroblast cultures by defined factors. Cell 126: 663-676, 2006.

31. Wernig M, Meissner A, Foreman R, Brambrink T, Ku M, Hochedlinger K, Bernstein BE and Jaenisch R: In vitro reprogramming of fibroblasts into a pluripotent ES-cell-like state. Nature 448: 318-324, 2007.

32. Kondo T, Setoguchi T and Taga T: Persistence of a small subpopulation of cancer stem-like cells in the C6 glioma cell line. Proc Natl Acad Sci USA 101: 781-786, 2004.

33. Haraguchi N, Utsunomiya T, Inoue H, Tanaka F, Mimori K, Barnard GF and Mori M: Characterization of a side population of cancer cells from human gastrointestinal system. Stem Cells 24: 506-513, 2006
34. Chiba T, Kita K, Zheng YW, Yokosuka O, Saisho H, Iwama A, Nakauchi $\mathrm{H}$ and Taniguchi H: Side population purified from hepatocellular carcinoma cells harbors cancer stem cell-like properties. Hepatology 44: 240-251, 2006

35. Szotek PP, Pieretti-Vanmarcke R, Masiakos PT, Dinulescu DM, Connolly D, Foster R, Dombkowski D, Preffer F, Maclaughlin DT and Donahoe PK: Ovarian cancer side population defines cells with stem cell-like characteristics and Mullerian inhibiting substance responsiveness. Proc Natl Acad Sci USA 103 11154-11159, 2006.

36. Wu C, Wei Q, Utomo V, Nadesan P, Whetstone H, Kandel R, Wunder JS and Alman BA: Side population cells isolated from mesenchymal neoplasms have tumor initiating potential. Cancer Res 67: 8216-8222, 2007.

37. Ginestier C, Hur MH, Charafe-Jauffret E, Monville F, Dutcher J, Brown M, Jacquemier J, Viens P, Kleer CG, Liu S, Schott A, Hayes D, Birnbaum D, Wicha MS and Dontu G: ALDH1 is a marker of normal and malignant human mammary stem cells and a predictor of poor outcome. Cell Stem Cell 1: 555-567, 2007.

38. Charafe-Jauffret E, Ginestier C, Iovino F, Wicinski J, Cervera N, Finetti P, Hur MH, Diebel ME, Monville F, Dutcher J, Brown M, Viens P, Xerri L, Bertucci F, Stassi G, Dontu G, Birnbaum D and Wicha MS: Breast cancer cell lines contain functional cancer stem cells with metastatic capacity and a distinct molecular signature. Cancer Res 69: 1302-1313, 2009.

39. Kim H, Lapointe J, Kaygusuz G, Ong DE, Li C, van de Rijn M, Brooks JD and Pollack JR: The retinoic acid synthesis gene ALDH1a2 is a candidate tumor suppressor in prostate cancer. Cancer Res 65: 8118-8124, 2005

40. Huang EH, Hynes MJ, Zhang T, Ginestier C, Dontu G, Appelman H, Fields JZ, Wicha MS and Boman BM: Aldehyde dehydrogenase 1 is a marker for normal and malignant human colonic stem cells (SC) and tracks SC overpopulation during colon tumorigenesis. Cancer Res 69: 3382-3389, 2009.

41. Jiang F, Qiu Q, Khanna A, Todd NW, Deepak J, Xing L, Wang H, Liu Z, Su Y, Stass SA and Katz RL: Aldehyde dehydrogenase 1 is a tumor stem cell-associated marker in lung cancer. Mol Cancer Res 7: 330-338, 2009.

42. Naka N, Takenaka S, Araki N, Miwa T, Hashimoto N, Yoshioka K, Joyama S, Hamada K, Tsukamoto Y, Tomita Y, Ueda T, Yoshikawa $\mathrm{H}$ and Itoh K: Synovial sarcoma is a stem cell malignancy. Stem Cells 28: 1119-1131, 2010.

43. Tokuzawa Y, Kaiho E, Maruyama M, Takahashi K, Mitsui K, Maeda M, Niwa H and Yamanaka S: Fbx15 is a novel target of Oct $3 / 4$ but is dispensable for embryonic stem cell self-renewal and mouse development. Mol Cell Biol 23: 2699-2708, 2003.

44. Maruyama M, Ichisaka T, Nakagawa M and Yamanaka S: Differential roles for Sox 15 and Sox 2 in transcriptional control in mouse embryonic stem cells. J Biol Chem 280: 24371-24379, 2005.

45. Brunk BP, Martin EC and Adler PN: Drosophila genes posterior sex combs and suppressor two of zeste encodes proteins with homology to the murine bmi-1 oncogene. Nature 353: 351-353, 1991.

46. Lessard J and Sauvageau G: Bmi-1 determines the proliferative capacity of normal and leukaemic stem cells. Nature 423: 255-260, 2003 .

47. Haupt Y, Alexander WS, Barri G, Klinken SP and Adams JM: Novel zinc finger gene implicated as myc collaborator by retrovirally accelerated lymphomagenesis in $\mathrm{E}$ mu-myc transgenic mice. Cell 65: 753-763, 1991.

48. Mitsui K, Tokuzawa Y, Itoh H, Segawa K, Murakami M, Takahashi K, Maruyama M, Maeda M and Yamanaka S: The homeoprotein Nanog is required for maintenance of pluripotency in mouse epiblast and ES cells. Cell 113: 631-642, 2003

49. Ho MM, Ng AV, Lam S and Hung JY: Side population in human lung cancer cell lines and tumors is enriched with stem-like cancer cells. Cancer Res 67: 4827-4833, 2007.

50. Ding XW, Wu JH and Jiang CP: ABCG2: a potential marker of stem cells and novel target in stem cell and cancer therapy. Life Sci 86: 631-637, 2010. 